\title{
Thermal Design of LNG Cabin on Sea Transports
}

\author{
Rong LI, Xuda SHAN, Juyong ZHANG \\ School of Mechanical Engineering, Hangzhou Dianzi University, Hangzhou, China, 310018
}

\begin{abstract}
The LNG (Liquefied Natural Gas) cabin is a key component in the maritime transport of $-163^{\circ} \mathrm{C}$ LNG. The cryo-insulation performance of cabin directly affects the security of LNG transport greatly. Based on a $10000 \mathrm{~m}^{3} \mathrm{LNG}$ ship, two structural schemes of the LNG cabin are certain, which include their materials, supports and parameters. One is two single cylinder with $5000 \mathrm{~m}^{3}$, the other is a vertical cylinder with 10000 $\mathrm{m}^{3}$. With the safety requirements of cryopreservation of $-163^{\circ} \mathrm{C} \mathrm{LNG}$, it calculates the heat leakage of two schemes. Lastly, the temperature field distributions of two types of LNG cabins with full load are simulated by $3 \mathrm{~d}$ mathematic models by finite element software.
\end{abstract}

KEYWORD: LNG; cargo tank; heat-insulating layer; thermal design

\section{INTRODUCTION}

Nowadays, as a product of natural gas, LNG (Liquefied Natural Gas) mainly relies on import over sea in most of countries. Since the boiling point of LNG is $-163^{\circ} \mathrm{C}$ under standard pressure, it needs maintain the ultra-low temperature during its transportation. The LNG cabin is used to load the $163^{\circ} \mathrm{C}$ LNG, which must be protected strictly from ocean shipping environment. Therefore, the cryoinsulation performance of cabin directly affects the security of LNG transport greatly. And the thermal design of cabin becomes its design point. Based on a $10000 \mathrm{~m}^{3}$ LNG ship, a structural \& thermal design of its LNG cabin is put out. In order to ensure its security of cabin, under thermal design requirements, the thermal performance of cabin must be checked strictly.

\section{LNG CABIN}

Film type cabin and independent ball type cabin are two main kinds of LNG cabin used in LNG ship. There are ripple structures on inner wall of film type cabin usually, and the internal structure of film type cabin is often simple with $98 \%$ volume utilization rate. The cabin structure consists of two shielding structures: the main shielding structure and the secondary shielding structure. Besides, it needs a metal thin film additionally provided insulation structure in the cabin structure to ensure its heat insulation. While the independent type cabin and the hull is independent of each other. The weight of its cabin is undertakes by itself. Therefore, there is no deformation or stress concentration on the hull itself.

In order to ensure the safety and efficiency of the LNG ship during its transportation, there are many strict requirements on its cabin in the design of LNG ship. At present the common types of LNG ship are as follows. And the cabin is usually made of $9 \%$ nickel thick plate or low temperature resistant aluminum alloy, with polyurethane foam. There is also a secondary screen wall structure outside of cabin, to prevent LNG leakage.

With tiny heat, $-163{ }^{\circ} \mathrm{C}$ LNG will generate vaporization, and its volume rapidly increases more than 600 times at the same time. The vaporized gas mixed with air easily explodes. In the process of transportation, the security of LNG dependents on thermal insulation performance of LNG cabin.

\section{STRUCTURE DESIGN OF LNG CABIN}

In the first scheme, $10000 \mathrm{~m}^{3} \mathrm{LNG}$ is divided into two cabins with $5000 \mathrm{~m}^{3}$ volume. Since LNG ship is $120 \mathrm{~m}$ long and $20 \mathrm{~m}$ wide, the size of LNG cabin is restricted by the size of ship, as shown in Table 1 . 
Table. 1 Parameters of $5000 \mathrm{~m}^{3}$ single cylinder cabin

\begin{tabular}{|c|c|c|c|c|c|}
\hline Diameter of cabin & Length of cabin & Volume of cabin & Vertical gap & Length of ship & Width of ship \\
\hline $15 \mathrm{~m}$ & $33.5 \mathrm{~m}$ & $5036.365 \mathrm{~m}^{3}$ & $5 \mathrm{~m}$ & $120 \mathrm{~m}$ & $20 \mathrm{~m}$ \\
\hline
\end{tabular}

Nowadays, the cabin is usually made of low temperature aluminum-killed steel, $9 \%$ nickel steel, and $\mathrm{Cr}-\mathrm{Ni}$ austenitic. Since stress of aluminum alloy is the minimum among three materials, it is not suitable for cabin for its large thickness wall. The parameters of the other two materials are shown in Table 2.

Table. 2 Comparison of two materials

\begin{tabular}{|c|c|c|c|}
\hline Material & Allowable stress & Minimum design pressure & Weight of cabin \\
\hline $9 \%$ nickel steel & $213 \mathrm{Mpa}$ & $3.5 \mathrm{Mpa}$ & $211 \mathrm{~T}$ \\
\hline Cr-Ni austenitic & $150 \mathrm{Mpa}$ & $2.74 \mathrm{Mpa}$ & $292 \mathrm{~T}$ \\
\hline
\end{tabular}

With low hardness, moderate intensity, plasticity, toughness, good mechanical properties, good welding performance, $\mathrm{Cr}-\mathrm{Ni}$ austenitic is more suitable for LNG cabin. To prevent heat leakage, LNG cabin is arranged on the other surface with $300 \mathrm{~mm}$ polystyrene insulation materials, through special adhesive adhesion. To protect layer polyethylene foam, $0.5 \mathrm{~mm}$ galvanized steel sheet is on the most outer layer.
In the second scheme, vertical cylindrical cabin structure includes outer cabin and inner cabin. A cylinder cabin with a bottom plate consist the inner cabin, with 9\% nickel steel. A vault, cylinder cabin and floor board consist the outer cabin, with carbon steel for it is not contact LNG directly. The structure and parameters of $10000 \mathrm{~m}^{3}$ vertical cylinder cabin are shown in Table 3.

Table.3 Parameters of vertical cylinder cabin

\begin{tabular}{|c|c|c|c|c|c|c|c|}
\hline Item & Filler & $\begin{array}{c}\text { Geometric } \\
\text { volume }\end{array}$ & $\begin{array}{c}\text { Effective } \\
\text { volume }\end{array}$ & $\begin{array}{c}\text { Evaporation } \\
\text { rate }\end{array}$ & Material & Diameter & Height \\
\hline Inner tank & LNG & $11200 \mathrm{~m}^{3}$ & $10404 \mathrm{~m}^{3}$ & $0.046 \%$ & $9 \%$ nickel steel & $24 \mathrm{~m}$ & $15 \mathrm{~m}$ \\
\hline Outer tank & Nitrogen, pearly sane & -- & -- & -- & Q345R & $28 \mathrm{~m}$ & $17 \mathrm{~m}$ \\
\hline
\end{tabular}

Insulation structure of vertical cylinder cabin includes top cabin, bulkhead and bilge. The top cabin is made of low carbon steel, concrete and $9 \%$ nickel steel. To prevent thermal deformation, 9\% nickel steel and expanded perlites consist of bulkheads with a layer of elastic mat inside. There is a ring bottom around the insulation beam in bilge, for bearing the weight of cabin and LNG, contacting heat transfer and hull. Perlite concrete is used as thermal insulation in vertical cylinder cabin, while foam glass brick is used in bilge heart part. The parameters of insulation materials in vertical cylinder cabin are shown in Table 4.

Table.4 Parameters of insulation materials in vertical cylinder cabin

\begin{tabular}{|c|c|c|c|c|c|c|c|c|c|c|}
\hline Item & \multicolumn{2}{|c|}{ Vault } & \multicolumn{2}{c|}{ Ceiling } & \multicolumn{2}{c|}{ Inner cabin } & \multicolumn{4}{c|}{ Bottom } \\
\hline Material & $\begin{array}{c}\text { Low } \\
\text { carbon } \\
\text { steel }\end{array}$ & $\begin{array}{c}\text { Concr } \\
\text { ete }\end{array}$ & $\begin{array}{c}9 \% \text { nickel } \\
\text { steel }\end{array}$ & $\begin{array}{c}\text { Glass } \\
\text { fiber }\end{array}$ & $\begin{array}{c}9 \% \\
\text { nickel } \\
\text { steel }\end{array}$ & $\begin{array}{c}\text { Expaned } \\
\text { perlite }\end{array}$ & $\begin{array}{c}\text { Foam } \\
\text { glass }\end{array}$ & Sand & $\begin{array}{c}9 \% \text { nickel } \\
\text { steel }\end{array}$ & $\begin{array}{c}\text { Concret } \\
\mathrm{e}\end{array}$ \\
\hline $\begin{array}{c}\text { Thermal } \\
\text { concuctivity W } \\
(\mathrm{m} \cdot \mathrm{K})\end{array}$ & 11.6 & 0.70 & 10.2 & 0.038 & 10.2 & 0.05 & 0.049 & 0.269 & 10.2 & 0.7 \\
\hline Thickness mm & 6.8 & 350 & 5 & 1200 & 6 & 1000 & 430 & 300 & 16.7 & 100 \\
\hline
\end{tabular}

\section{SUPPORTING STRUCTURE AND HEAT LEAKAGE}

Single cylinder cabin is horizontal, supported by two bearings. One of support is mobile, for avoiding gravity by bending and additional stress. The support is a double-layer compression wood filled with epoxy mortar pad for insulation. Assuming environment temperature is $40^{\circ} \mathrm{C}$, heat leakage of single cylinder cabin is calculated from formula (1).

$$
\mathrm{Q}=\mathrm{qA}=\alpha\left(T_{2}-T_{1}\right) \mathrm{A}
$$


Here, Q-heat transfer of cabin unit area, $\mathrm{W} / \mathrm{m}^{2} ; \alpha$ total heat transfer coefficient of cabin, W/ $\left(\mathrm{m}^{2} \cdot \mathrm{K}\right) ; \mathrm{T}_{1}$-temperature of inner cabin, $\mathrm{K} ; \mathrm{T}_{2}$ temperature of outer cabin, K; A- insulation area of cabin wall, $\mathrm{m}^{2}$. The total heat leakage is $100.584 \mathrm{KW}$, meeting thermal requirements of LNG cabin. (2).

The evaporation rate is calculated from formula

$$
\alpha=\frac{Q \times 24}{\gamma V \rho} \times 100 \%
$$

Here, $\gamma$-evaporation potential of LNG, $142 \mathrm{~kJ} / \mathrm{kg}$; $\mathrm{V}$-volume of cabin, $\mathrm{m}^{3} ; \rho$-density of LNG, $425 \mathrm{~kg} /$ $\mathrm{m}^{3}$; Q-total heat, W. The result is $0.000794 \%$, which meets design needs.

For vertical cylindrical cabin, there is an annular pillar structure without cooling tube in pillar space to support cabin. Its heat leakage of cabin bottom is calculated by formula (3).

$$
\varphi_{b}=\frac{T_{b}-T}{R_{b}}
$$

Here, $\mathrm{T}_{\mathrm{b}}$-average temperature of cabin bottom, $275 \mathrm{~K}$; T-temperature of system, $112 \mathrm{~K} ; \mathrm{R}_{\mathrm{b}}$-thermal resistance of cabin bottom, $0.275 \mathrm{~K} / \mathrm{W}$. The result is $5.564 \mathrm{KW}$. Its heat leakage of cabin side wall is calculated by formula (4).

$$
\varphi_{c}=\frac{T_{\infty}-T_{c x}}{R_{e}}
$$

Here, $\quad \mathrm{T}_{\infty}$-ambient temperature, $\mathrm{K} ; \mathrm{T}_{\mathrm{cx}}{ }^{-}$ temperature of annular space between inner wall and outer wall of cabin, $\mathrm{K} ; \mathrm{R}_{\mathrm{c}}$-thermal resistance of inner layer of cabin, K/W. The result is $0.901 \mathrm{KW}$. Its heat leakage of cabin top is calculated by formula (5).

$$
\varphi_{r_{,} d}=\frac{\sigma_{b}\left(T_{\infty}^{4}-T_{d x}^{4}\right)}{R_{r_{i} d}}
$$

Here, $\mathrm{R}_{\mathrm{r}, \mathrm{d}}$-thermal radiation resistance of top cabin, $\mathrm{K} / \mathrm{W} ; \mathrm{T}_{\infty}$-ambient temperature, $\mathrm{K} ; \mathrm{T}_{\mathrm{dx}^{-}}$ temperature of space between cabin wall and top cabin, $\mathrm{K} ; \sigma_{\mathrm{b}}$-Stefsn Boltzmann constant, 5.67×10$8 \mathrm{~W} /\left(\mathrm{M}^{2} \cdot \mathrm{K}^{4)}\right.$. The result is $27.78 \mathrm{KW}$. Total heat leakage of vertical cylindrical cabin is: $\varphi=\varphi_{\mathrm{b}}+\varphi_{\mathrm{c}}+\varphi_{\mathrm{r}, \mathrm{d}}=34.245 \mathrm{KW}$, which less than the design requirements of $250 \mathrm{KW}$.

The evaporation rate of vertical cylindrical cabin is calculated from formula (6).

$$
\alpha=\frac{Q \times 24}{\gamma V \rho} \times 100 \%
$$

Here, $\gamma$-evaporation potential of LNG, $142 \mathrm{~kJ} / \mathrm{kg}$; $\mathrm{V}$-volume of cabin, $\mathrm{m}^{3}$; $\rho$-density of LNG, $425 \mathrm{~kg} /$ $\mathrm{m}^{3}$; Q-total heat, W. The result is $0.00012 \%$, which meets design needs.

\section{THERMAL SIMULATION OF CABIN INSULATION STRUCTURE}

With the help of "Ansys" finite element software, the numerical simulation of LNG two types of cabin are. And the effectiveness is also verified. In view of LNG cabins are axial symmetry structures, the numerical models of two cabins are simplified during thermal analysis.

Single cylinder cabin is $33.5 \mathrm{~m}$ long and in $7.5 \mathrm{~m}$ radius, with 3 layers of insulation material. The thickness and properties of insulation materials are shown in Table 5. According to design requirements, temperature of $\mathrm{LNG}$ in cabin is $-163^{\circ} \mathrm{C}$, temperature of environment is $40{ }^{\circ} \mathrm{C}$, and the convection coefficient is $12.5 \mathrm{~W} / \mathrm{m}^{2} \cdot{ }^{\circ} \mathrm{C}$. Its thermal simulation result is shown in Figure 1.

Table.5 Thickness and parameters of single cylinder cabin insulation materials

\begin{tabular}{|c|c|c|}
\hline Item & Thermal conductivity/W $(\mathrm{m} \cdot \mathrm{K})$ & Thickness/mm \\
\hline Cr-Ni austenitic & 16 & 30 \\
\hline Polystyrene foam & 0.116 & 300 \\
\hline Zinc plate & 116 & 0.5 \\
\hline
\end{tabular}

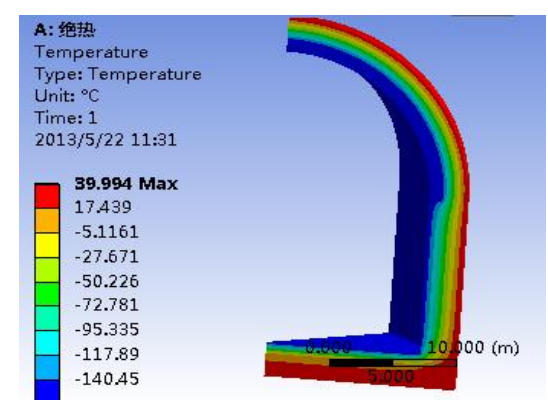

Figure 1 Simulation result of single cylinder cabin

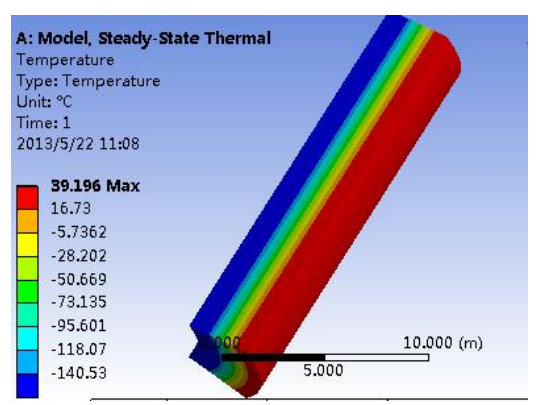

Figure. 2 Simulation result of vertical cylinder cabin 
For the second scheme, insulation material of vertical cylindrical cabin is relatively complex. The thickness and properties of its insulating material layer are shown in table 4. Similarly, temperature of $\mathrm{LNG}$ in cabin is $-163^{\circ} \mathrm{C}$, temperature of environment is $40{ }^{\circ} \mathrm{C}$, and the convection coefficient is 12.5
$\mathrm{W} / \mathrm{m}^{2} \cdot{ }^{\circ} \mathrm{C}$. Its thermal simulation result is shown in Figure 2.

As shown above, temperature distributions of two types of cabin are basically meet the design requirements. But two schemes of cabin are different in application process still, which are shown in Table 6.

Table.6 Two scheme comparison of LNG cabins

\begin{tabular}{|c|c|c|}
\hline Item & Single cylinder cabin & Vertical cylinder cabin \\
\hline${\text { Volume} / \mathrm{m}^{3}}^{\prime}$ & $5000 \times 2$ & 10000 \\
\hline Heat leakage/KJ & 50.292 & 34.245 \\
\hline Daily evaporation rate/\% & 0.046 & 0.0012 \\
\hline Safety & Normal High \\
\hline Cost of manufacturing & Cheap & Expensive \\
\hline Difficulty of technology & Normal & Complex \\
\hline Support structure & Sliding bearing and fixed bearing & Group of stainless steel tube \\
\hline Consumption of insulation material & Less & More \\
\hline
\end{tabular}

Comprehensive consideration of safety, scheme of vertical cylindrical cabin is adopted lastly.

\section{SUMMARY}

This paper mainly analyzes two types of $10000 \mathrm{~m}^{3}$ cabin on LNG ship. Then two typical cabins are studied from their insulation structure, supporting structure, heat leakage and daily evaporation rate. At last, scheme of vertical cylindrical cabin is adopted as final scheme.

\section{ACKNOWLEDGEMENTS}

This research was financially supported by the Project supported by the Zhejiang Provincial Natural Science Foundation of China (No. LQ13E060004). This work was supported by Zhejiang Open
Foundation of the Most Important Subjects (No. 201205).

\section{REFERENCES}

[1] Chen Ruiquan, Lu Sheng. Study on C-type LNG tank design. Ship engineering. 2013, 1:11-13, 69.

[2] Pei Yiqun, Lu Sheng, Liu Wenhua. Structural design and research of type-C independent tank on small scale LNG ship. Journal of ship design. 2012, 2:28-34.

[3] China Classification Society. Rules for materials and welding 2009. Beijing. China Communications Press. 2009.

[4] The editorial board of Pressure vessel technology series. Pressure vessel design knowledge. Beijing. Chemical Indusrry press. 2005.

[5] Ship carrying liquefied gases in bulk and equipment specification. Dalian. China Classification Society. 2006.

[6] Manual calculation of pressure vessel GB150,151. Beijing. China pressure vessel standardization committee. 2001. 